\title{
Students' Perception of English Teacher and Apprentice Teacher on Learning English (A Case Study of Elementary School in Southern Thailand)
}

\author{
Yoga Prihatin ${ }^{1}$, Sumartono $^{2}$, Ihda Rosdiana ${ }^{3}$, Riza Prawitasari $^{4}$ \\ Universitas Pancasakti Tegal ${ }^{1,2,3,4}$ \\ \{yogaprihatin@yahoo.com¹, smart.onpbi@gmail.com², ihdarosdiana@gmail.com³, \\ prawitasari.riza@yahoo.com ${ }^{4}$ \}
}

\begin{abstract}
The perception in English language teaching for young learners has been known to see how the learning process perceived for both of students and teacher. Therefore it is important to conduct the students' perception on how their teacher performance especially in teaching young learners. The purposes of this research are to describe the students' perception on their English teacher, apprentice teacher and the differences for both teachers among young learners students. Based on the analysis, the researcher found the result shows that the students perceived their English teacher and apprentice teacher almost the same in the aspects of the questionnaire. The English teacher got 1643 while the apprentice teacher got 1601 for the total score.
\end{abstract}

Keywords: Students’ Perception, Teacher, Apprentice Teacher, Young Learner

\section{Introduction}

Students who study in the elementary school are very dependent. Young learners students need a classroom activities which is short and let them explore about what things they need to learn. It is necessary to be in charge of the classroom, giving clear instructions and dealing effectively with learning strategies and classroom management. In teaching young learner, they need to be motivated yet they need to be engage in every classroom activities which encourage them to learn as long as they perceive it to be fun as young learners are considered has less motivation. Therefore, here the role of teacher is very important because they guide the students to enjoy and create fun learning to make sure the students keep motivated to learn.

Perception is related to the point of view of something. The perception can give the image to know furthermore about something as according to Crotty as cited in (Pertiwi et al., 2020) it purpose is to see someone point of view on something which is very subjective because it depends on some external and internal factors. Perception on teacher is used to measure the framing of overall learning process and the performance of the teacher itself especially when it comes to young learners.

Teaching English for kids is not easy for the teachers (Pertiwi et al., 2020), There are challenges for them as they have to turn their L1 or first language to L2 or foreign language. 
The characteristics of the elementary students are suitable for teacher to provide appropriate classroom where the young learners are ready to like the material being brought, when it comes in the term of foreign language, students need to be brought to the interest of the language as if they learn a new language and maximized learning accelerates. Here the teacher should create and promote this atmosphere and provide the materials along the needs of the objectives of the material and the students. Thus, the perspective on teacher needed to carry out the suitable material and learning process to teach the students especially young learners.

Drawing on the situation presented above, the research conduct a research along the needs of English Language Teaching as Foreign Language in Thailand where the research became apprentice Teacher in Ban Thamapraw School, an elementary school as English Teacher to fulfill the goal of English language acquisition as Foreign Language, that is communicative learning which is focused on basic conversation ability.

This study purposed to figured out the students' perceptions of a young learners English Teacher in the term of qualities related to his or her professional profile compared to the apprentice teacher which is the researcher itself which include personality trait, competence in English, classroom management, teacher's method and techniques, and assessment \& feedback.

\section{Literature Review}

\subsection{English Learning for Young Learners}

How do children learn language? Children obtain their native language without formal education and there are some theories relating the language acquisition process. Chomsky as cited in (Fitrawati, 2013) assumed that learning was inherited, in the sense that every child has a capability to learn a new language. Another theory stated by Vygotsky as cited in (Fitrawati, 2013) assumed that language bring the cognitive development on children, and the help of the adult learn and develop while Piaget believed that there are stages of children to be able to learn and develop the language, they are :

a. Sensory Motor Stage (from $0-2$ years ) which children likely to learn through the engagement of physical activities and the society around them.

b. Pre-Operational Stage (from $2-7$ years) when children require concrete situation to process ideas.

c. Concrete Operational Stage (from $7-11$ years) when the children begin conceptualize and start to learn abstract thing and problem solving as well.

d. Formal Operational Stage (from 11-15) abstract thinking approved.

Young learners also learn in different way, according to Berman as cited in (Fitrawati, 2013), children has their own preferred style in learning, especially when learning foreign language. They may be characterized as visual learners as if they see what is happening through their vision then link it to their understanding, they may also be characterized as audio learner where they understand through sound and the last they also may be characterized as kinesthetic learner, it is where the children learning process involves physical movement to innate their understanding. 


\subsubsection{Characteristic of Children}

There are some expert picturize the characteristics of children and children knowledge's development. Scott as cited in (Fitrawati, 2013) states that children in pre-school or primary setting in generally learn by many of physical activities (learning by doing). It means that they learn by experiencing things and engaging their senses as well as they practice something. It means that the process of learning have to go well beyond the visual and auditory way to go along toward helping children internalize the language acquisition.

\subsubsection{Teaching English for Young Learners}

According to Hamer as cited in (Jazuly, 2018) children are born with a natural sources and interest for learning, and their desire to learn should be adhere when they begin school, therefore many beliefs that the sooner the young learners' start to learn English, the better it will be. Here, as young learners, teacher playing important roles to provide attractive learning as children are not able to learn abstract things. Different methods will support a material and the acquisition of the language. Teachers have to be creative and innovative in order to make a fun and interesting atmosphere in their class. Children like to engage with movement and physical participation, the more fun the learning is, the better language acquisition reached. This is because they did not memorize by directly memorize it or learn in abstract way but they learn with the world surroundings.

\subsubsection{Reasons for Young Learner to Study English}

The benefits of early language learning, as critical period is existing, it is earlier to puberty in which children could acquire native-like proficiency in a foreign language (Jazuly, 2018). A recent results of research on the critical period stated by Marinova-Todd, Marshall \& Snow as cited (Pertiwi et al., 2020) concluded that adolescent learners are more efficient learners on language with the acquisition of the mother tongue so that they can learn a second language in maximum. This points out that language learning for early age is very effective and efficient with these optimal conditions in mind, then, there are a number of reasons for starting language learning early. These include:

a. The value of increased time,

b. The possibility of better pronunciation and fluency,

c. The possibility of greater global awareness and intercultural competence,

d. The value of bilingualism.

Thus, teaching English to young learners assumed to be more effective and reveal a better accomplishment on the language development itself by years a long with the growth of child.

\subsection{Perception}

According to Cambridge Dictionary (2020), perspective is related to the point of view of something. Perspective is about the image to know furthermore about something in one point of view. The experience of human sensing things around him is the main affect their perspective as it coming through the stimulans he accepted from the nerves to the brain. However it engages the work of the senses. Perception is related to the giving of meaning, description, interpretation towards certain object done by human. 


\subsubsection{The Process of Creation of Perception}

Perception, according (Sari, 2019) is the result of action and reaction. To create a perception in an individu, there are pre-requirement condition:

a. The object of perception, as object stimulates the senses, it comes from outside catched by the sensor and it goes through the nerves which is receptors.

b. The Receptors, it is the tool to accept the stimulans. Along with censory nerves, they bring information to the brain.

c. Attention, the first step in catching the action through the receptors, without paying attention, there will be no perception.

Based on the explanation above, it can be concluded that the receptions is not consist of only one sense of feeling but also the other, it may be complex as it very depends on the receptors and the factors determine it. The perception itself has three factors, the first is the absorbance of the action outside of an individu caught by the stimulans, defining the object or the stimulation through the understanding, and the evaluation of the individu on the object itself. Take for the example, there is a picture of an morning scenery, the eye will react to the stimulation by sending the information to the brain, then the brain will define whether it is a good picture or not after paying attention to the picture, then the perception will be created, the picture is good but maybe one individu has ever seen a much more beautiful picture, then the perception of the picture will be under his or her favorite picture. This is how the perception create in one life. The perception in this research is adapted from the journal of Rana Yildirim and Yesim Dogan which discussed eight types of students perception on their teacher include teacher's personality trait, competence in English, classroom management, method, technique, media, textbook and assessment and feedback.

\subsubsection{Perception as Elements of EFL Education}

There is a relative poverty which related into the perceptions of teachers as to personal profile and methodological effectiveness of teaching towards students as Brandl in (Habeeb, 2013) particulary in the field of EFL there is a specific amount of research relating teacher performance in teaching, objective being measured on competencies, and alternative teaching methodologies.

Learning foreign language at an early age, EFL curriculum in education, challenges, beliefs about self-efficacy, beliefs on value or effectiveness of defined training and teaching methodologies, measures of self-esteem, personal judgements of competence or language skill, and experience with stress in teaching and training environments (Habeeb, 2013). The concern served by the previous literature will be the questions of what general effect there is of the students' perception on those students' behavior and how it affect their learning process. More specific questions will be the effect of the fun learning they received, their motivation, the role of the teachers themselves, the relationship between teachers perceptions, students, and institutional policies, and the potential impact of perceptions on training methodology.

\subsection{Teacher}

A teacher has been defined differently by many experts but many beliefs that teacher defines as a person who teaches or facilitates the learning process and bridging the knowledge to the students. It is widely believed that a person who has been registered by the commissioner for education and being given a teaching lisence from an institutions in 
education will be regarded as a teacher. Based on (Susanti et al., 2015) cited in Teaching English to Young Learners' book, a teacher is the only profession who is capable of planting knowledge and shaping the youths to the higher knowledge. Teachers are capable of creating the youths because their role may determine the students' life and impact on the future of the youths itself. Both teachers and parents grow with the children for a long time and they are capable of transferring the knowledge, skills and values that cannot be easily challenged by the society.

\subsubsection{Apprentice Teacher}

The apprenticeship in the level of university and the effects of professional progress on teaching of English will be analyzed. In this context, the process of pre-service in teaching training and in-service training programs is regarded as vital components of teachers' professional developments (Er et al., 2012) as it belongs to apprenticeships. For English as a Foreign Language (EFL), effective teacher can be interpreted as the one who leads the students to the comprehension in English (Er et al., 2012), teachers have to require eight roles as cited in (Er et al., 2012), they are planner, informer, manager, monitor, involver, parent/friend, diagnostician, and resource. Therefore, the apprenticeship in the universities is needed to carry out good qualities of teachers and getting know the current system used in the education.

It can be concluded that there is different between the teacher and apprentice teacher. As apprentice teacher considered teaching in a short term, temporary and compulsory for entry to the next level of education.

\subsubsection{Qualities of A Good Teacher}

Teachers should be good role model in the teaching and learning process. It is vital to acquire to the following principles to become one; reflection on the learning process, patience, justice, feelings, understanding, the learning environment, knowing learning differences, relationship, problem solving and mastery of the subject, discipline, interaction and motivation. Every teacher is expected to have such qualities in order for him or her to be regarded as a true teacher (Gervas Zombwe, 2014). A successful teacher is expected to have qualities depicted in the following chapters as stated Donna cited in (Gervas Zombwe, 2014):

a. Should be knowledgeable in terms of what he or she teaching, the teacher who is versed will be able to teach confidently. well qualified and knowledgeable teacher does well in the learning and teaching process.

b. Should know the teaching methodologies as well as education psychology, a teacher is also expected to have skills on teaching that will enable him or her to administer on their duty. Also the teacher is expected in promoting different potentials among pupils.

c. Should have a sense of humour and love his or her pupils.

d. To have a positive attitudes, to solve all the problems that occur in the course of teaching.

e. To have a high expectations, a teacher should prepare his or her pupils so they have a high expectation in relation to their academic achievement.

f. Knowing of justice and democracy, teacher who knows justice treats all the students fairly.

g. Should be a role model, have a hardworking spirit, diligent, honest and a good manner so that children will adapt it.

h. Flexible and Curious. 


\subsubsection{Teacher's Need}

Relating to the needs of the teacher, it means fulfilling the needs that would acquire them to be qualified teacher. Good teachers are important for quality teachers. Research shows that most of the students who is well in their examinations result do not interest to become a teacher (Gervas Zombwe, 2014). This is because the teaching process is not attractive. Therefore, it is important to fulfill the needs of the teachers which consists by these aspects as follows:

a. Salaries and other benefits, the teachers salary should enable them to earn a life. As teacher is a profession, they needs money for paying life needs, food, rent and fare, medical cover, etc.

b. Security and Good living environment

c. Leadership and administration of education institutions, leadership plays important role on the education institution itself.

d. Training and Professional development for teachers, the teacher needed to keep learning, it is beneficial to lift up their efficiency in teaching. Teachers should be engage with, trained and oriented to the new changes in academic advances.

e. Participation of teachers in decision making,

f. The society whose cooperate with the teacher, the value of te society also support teacher. The society which is the parents should cooperate with the teachers so that children can be effectively taken care of at both school and home.

"Teacher needs" refers to the conditions that can be created by the policy environment, by administrative structures, or by teacher training, in order to foster better outcomes or a more favorable classroom experience for the individual instructor (Gervas Zombwe, 2014).

\subsubsection{Duties and Responsibilities of A Teacher}

Teacher with good values also teacher who has a key role to play while at school or at home (Jazuly, 2018). The following are some duties and responsibilities of a teacher:

a. To give knowledge and seeking potentials, a teacher has the responsibility to transfer knowledge according to each level of learners. In that matter, the delivery of the material and identification of the students' potential are the vital part of the learning process.

b. To facilitate the teaching and learning process, the teacher is supposed to preparing, planning, and facilitating the learning process. Well prepared teacher will teach effectively.

c. Keeping class records, to keep students' progress being noted and to make any other relevant feedback on the teacher's students.

d. To maintain and build discipline, teacher need to use various approaches to maintain discipline in the class.

e. Creative and researcher,

f. The role model, teacher should be a good role model in his or her own job, having a good behavior as well as hardworking spirit.

g. Facilitator, teacher is not only the source of knowledge but rather a facilitator in the learning process.

h. Evaluator, teacher is the evaluator on the pupils, curriculum evaluator, curriculum designer.

i. Solicitor the knowledge, teacher solicit the material used by learners.

j. Counselor and mentor, teacher also consulted to solve different problems in the society. 


\section{Methods}

This research will use descriptive qualitative analysis. (Marhamah, 2014) Descriptive qualitative are collecting the data, classifying, analyzing, interpreting, and finally drawing a conclusion. Descriptive research approach which will be used in this research project is to see the perception of the students (young learners) after being taught by the apprentice teacher and their English teacher, then to compare their perception on their English teacher to Apprentice teacher.

\subsection{The Subject of The Research}

The subject of this study is the third grade students of Ban Thamapraw Schoo in Thamapraw, Southern Thailand academic year 2019/2020. The researcher uses two classes with 17 students participant. The first class is fourth grade used to do a questionnaire try out and the second class is the third grade to do a questionnaire.

\subsection{Instrument of Research}

To obtain the data regarding perspective of students - a questionnaire is employed as a research instrument. Designed as a student response scale survey, the questionnaire is adapted from the Rana Yildrim and Yesim Dogan "Young learner English teacher profile from students' perspective" (2010). Widely adopted and adapted by several later researchers, the questionnaire from Yildrim and Dogan is a 31-item Likert-type scale questionnaire ranging from Strongly agree (5), Agree (4), Unsure (3), Disagree (2), and Strongly disagree (1) with regards to the three components of personality traits, competence in English, classroom management, method, technique, media, textbook, and assessment and feedback.

Following the first instrument, to obtain qualitative data the researcher conducts five Open-Ended Questions. Therefore, Open-Ended Questions are selected as a research approach in this study because it is a suitable method to catch information that is not seized by a questionnaire. Designed as a written response form, the Open-Ended Questions are used to gather students' opinions on students' perception towards their English teacher and Apprentice teacher.

\subsection{Validity and Reliability of Instruments}

To construct the validity and reliability test, the questionnaire which is adapted from Dogan and Yildirim then calculated according to Pearson Product Moment Correlations formula by the SPSS program before being distributed. The result of the validity reveals 22 questions from 31 questions for the variable of students' perception of English teacher and apprentice teacher.

The questionnaire item that significantly correlated with the total score indicates that the items are valid. The instrument is valid if the significance value scored smaller than 0.05 , then the instrument, and if the value of $r_{x y}$ scored greater than $r$ table product moment. Furthermore, the internal reliability of the items of questionnaire is also calculated using Cronbach's Alpha formula by SPSS program. The questionnaire items are declared reliable if the value of Cronbach's Alpha scored greater than 0.600 . 


\subsection{Data Collection and Analysis Procedures}

To collect the data, the questionnaire adapted from Rana Yildrim and Yesim Dogan (2010) is distributed to the participants. Each statement asks participants to rate on the scale ranging from Strongly agree (5), Agree (4), Unsure (3), Disagree (2), and Strongly disagree (1). The data obtained from questionnaire is divided into eight categories of students' perception toward their English teacher and Apparantice that are personality traits, competence in English, classroom management, method, technique, media, textbook, and assessment and feedback.

Following the questionnaire data collections, Open-Ended Questions distributed to the student's participants. Students are given five open-ended questions including participants feel about studying English, feel studying English with their English teacher, feel studying English with their Apprantice teacher, and describe their both English teacher.

\section{Result and Discussion}

The questionnaire was analyzed to find the students' pereception towards their English teacher, students' perception towards their Apprantice teacher and the differences of students' perception between English teacher and Apprantice teacher. The research findings obtained from the questionnaire were analyzed quantitatively using Statistical Packages in Social Sciences (SPSS). Eight categories of students' perception are presented in table 4.1. Whereas, table 4.2 shows all the statements were measured on a five-point Likert Scale:

Table 1. Questionnaire Categories

\begin{tabular}{lc}
\hline Categories & Number of Statements \\
\hline Personality traits & 1 to 3 \\
Competence in English & 4 \\
Classroom management & 5 to 7 \\
Method & 8 to 10 \\
Technique & 11 to 13 \\
Media & 14 to 16 \\
Textbook & 17 to 20 \\
Assessment and Feedback & 21 to 22 \\
\hline
\end{tabular}

Table 2. 5-Point Likert Scale

\begin{tabular}{cccccc}
\hline Range & Strongly agree & Agree & Unsure & Disagree & Strongly disagree \\
\hline Value & 5 & 4 & 3 & 2 & 1 \\
\hline
\end{tabular}

The questionnaire of a 22-item based on the eight categories of students perception with the percentage of the questions toward English teacher and Apprentice teacher can be described in a diagram below in : 


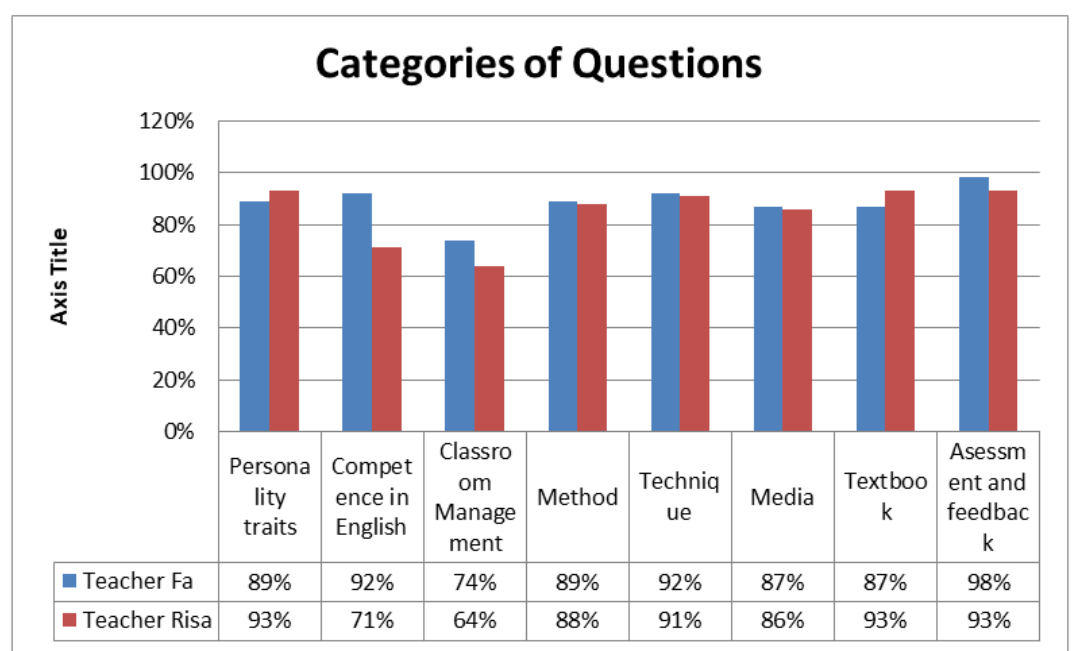

Fig. 1. Categories of Students' Perception on English Teacher and Apprentice Teacher. Adapted from Rana Yildrim and Yesim Dogan (2010)

It can be concluded that the result of students' perception on both teacher based the questionnaire are not significantly different, only two categories which get a bit sifgnificant differences, they are Competence in English category and Classroom management category. The differences in category of Competence in English is $21 \%$ and the difference on Classroom management is $10 \%$.

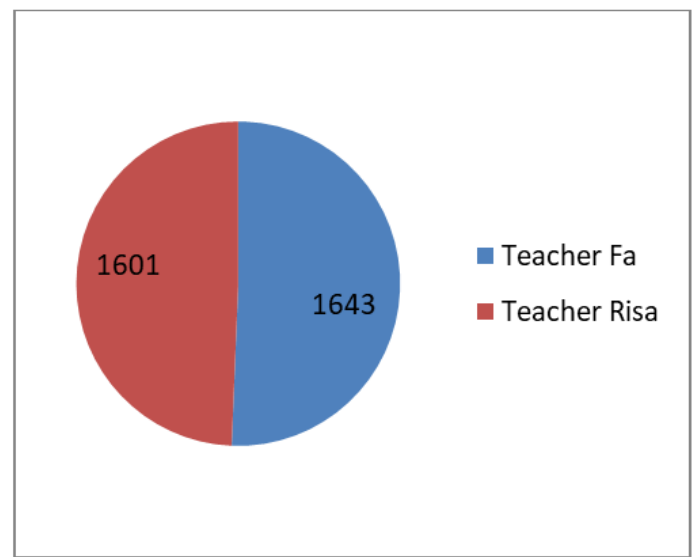

Fig. 2. Total Score of Students' Perception towards English Teacher and Apprentice Teacher

Based on the diagram above, it can be seen that the result for the apprentice and English teacher are likely the same. The apprentice teacher shows a small significant result on the score of the questionnaire. The students' perception towards their English teacher which is Teacher Fa here shows the result for the total score is 1643 from the answer of 17 students of Ban Thamapraw Elementary School, while the students' perception towards their apprentice teacher shows the result for the total score is 1601 . 


\section{The Differences on the Students' Perception between their English Teacher and Apprentice Teacher}

After being analyzed, it can be concluded that there are a quite different result of a questions between the English teacher and the apprentice teacher. Some questions shows a different perception of both teachers. The first is item number 2, the question is "My Engllsh teacher is always smiling" the result for teacher $\mathrm{Fa}$ is $78 \%$ while teacher Risa $88 \%$, it indicates that the apprentice teacher consider more friendly and the students concern about this personal trait.

The next is item number 4, the questions is "During learning English, my teacher translates English into Thailand language" the answers shows the score 71\% for teacher Risa compared to $92 \%$. It is understandable as the apprentice teacher is a non native speaker of Thailand language. Therefore, the students scored low on teacher Risa. Connected to the next number, the student also scored only $71 \%$ or teacher Risa for the questions "During teaching, my teacher always speaks clearly" compared to $97 \%$. It is maybe because the different dialects tht determine the clarity of the voice. In item number 7 with the question "During teaching English, my teacher creates a humor and exciting class" teacher Risa scored higher than the English teacher. It is $88 \%$ for teacher Risa and $79 \%$ for teacher Fa. It implies that teacher Risa is humorous and created exciting class more than the way teacher Fa did.

The researcher also spread the open-ended questions to the students to directly compare the English and apprentice teacher. On question "What do you feel learning English subject" all students of Ban Thamapraw Elementary School answered Very Happy and Happy. It indicates that that the learning activities and process were enjoyed by them, they feel learning English is not a hard deal for them. Next, in question "Do you like learning English?" all students answered "Yes", then the reasons are because they like to study with teacher Fa and teacher Risa, because it is fun, and because they are happy. As they are young learners, the answers are not complex.

Questions number three for open-ended questions is "Do you like learning English with Teacher Risa" all students answered Yes, I do. The answer or the reason why are because they happy to study with teacher Risa, because they like teacher Risa and because it is very interesting. Based on the answers, the apprentice teacher here were succeed in teaching young learners in Ban Thamapraw elementary students especially in third grade students, they assumed to give a good perception on their apprentice teacher during short period of learning process.

The next is the question which asked "Do you like learning English with Teacher Fa?" all students answered Yes, I do. The answers for the reasons are because they happy to study with teacher $\mathrm{Fa}$, because they like teacher $\mathrm{Fa}$ and because it is very interesting. The answers for both teachers are just the same. The last question is the question about their English teacher "Please describe your English teacher in your own words!" all of students answered that they like their English because the English teacher is kind, fun, like to playing games. They were also very happy when they were being taught by teacher Fa because she is fun and kind. Some of them also mention teacher Risa as the apprentice teacher who is kind and orderly and fun.

Based on the open-ended questions, it can be concluded that there is no significant different of the students perception on their English and apprentice teacher. All of them assume that their teacher are fun and kind and they were happy to be taught by them. Therefore, it can be concluded that to conduct a good teaching learning process, the teacher need to prepare and do some various activities, media, textbook, method, strategy and 
assessment so that the perception on their teacher will be satisfying. As perception is very subjective, both teachers are perceived good.

\section{Conclusion}

The objective of this tudy is to specify the profile of a YL English teacher from the students' perspectives. To do this, 17 third grade students studying English were asked to make reflections about what was actually happening in the classroom, how the teachers were implementing their practices and how the students perceived their English teachers' personal traits. Despite such limitations, this study has provided many implications for students, english teachers, and further researcher. This study has also revealed that that to conduct a good teaching learning process, the teacher need to prepare and do some various activities, media, textbook, method, strategy and assessment so that the perception on their teacher will be satisfying. As perception is very subjective, both teachers are perceived good.

\section{References}

[1] Er Mustafa., Ulgu S., Sari I.,. 2012. The Journey of ELT Teachers from Apprenticeship to Mastery. Turkish Air Force Academy: Istanbul.

[2] Gervas Zombwe. (2014). Who is a Teacher? Quality Teachers for Qualty Education. 1-15. http://hakielimu.org/files/publications/WHO IS A TEACHER_R.pdf

[3] Pertiwi, R. S., Salabiyati, I., Damara, D., Pratolo, B., W. (2020). The Teacher 's Perspectives About Challenges of Teaching English for Young Learners : A Case Study at English Course for Young Learners. Universitas Ahmad Dahlan: Yogyakarta. 397(Icliqe 2019), 65-74.

[4] Fitrawati. (2013). Teaching English For Young Learners "How They Learn and Pedagogical Implication". Universitas Negeri Padang: Padang. PEDAGOGI | Jurnal Ilmiah Ilmu Pendidikan Volume XIII No.2 November 2013. XIII(2), 62-66.

[5] Habeeb, K. M. (2013). Teachers 'Perceptions toward Implementing English as a Foreign Language at Kindergarten: What Can We Learn from the Case of Kuwaiti Kindergarten Teachers?. University of Arkansas: Fayetteville

[6] Jazuly, A. (2018). Guidence of Teaching English to Young Learners (TEYL) For Early Childhood Education Teachers at AD Dhuha Kindergarten of Jember. IKIP PGRI Jember: Jember. 1(2), 168-179.

[7] Marhamah, R. A. (2014). Interpersnolal Meaning Analysis of Muse Song Lyrics in Black Holes and Rvelations' Album (A Study Based on Systemic Functional Linguistics). 1-82.

[8] Sari, I. P. (2019). Pengaruh Pemanfaatan Sumber Belajar Dan Minat Belajar Terhadap Hasil Belajar IPS Kelas V SD Dabin I Kecamatan Tegal Barat Kota Tegal. Skripsi. Universitas Negeri Semarang: Tegal.

[9] Susanti, D E. (2015). The Investigation of Students' Perception of English Teacher and Their English Learning Motivation in The First Grade of Vocational High School 1 Tengaran. Skripsi. IAIN Salatiga: Salatiga.

[10] Yildrim, Rama., Dogan Yesim. 2010. Young Learner English Teacher Profile from Students' Perspective. Cukurova University: Turkey. 